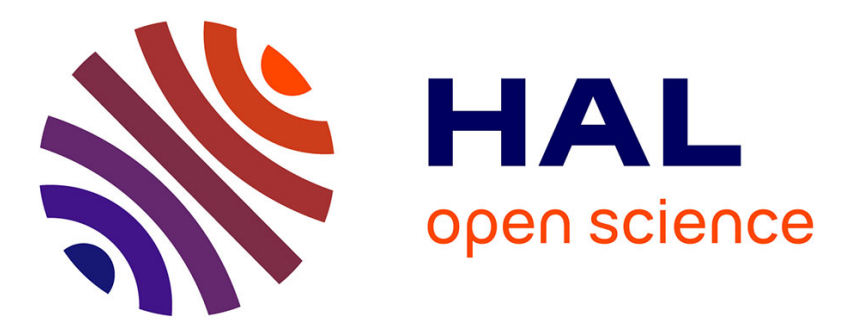

\title{
Tracing biogenic links of natural organic substances at the molecular level with stable carbon isotopes: n-Alkanes and n-Alkanoic acids from sediments
}

Eric Lichtfouse, James W. Collister

\section{- To cite this version:}

Eric Lichtfouse, James W. Collister. Tracing biogenic links of natural organic substances at the molecular level with stable carbon isotopes: n-Alkanes and n-Alkanoic acids from sediments. Tetrahedron Letters, 1992, 33 (52), pp.8093-8094. 10.1016/S0040-4039(00)74727-7 . hal-00175055

\section{HAL Id: hal-00175055 \\ https://hal.science/hal-00175055}

Submitted on 23 Nov 2007

HAL is a multi-disciplinary open access archive for the deposit and dissemination of scientific research documents, whether they are published or not. The documents may come from teaching and research institutions in France or abroad, or from public or private research centers.
L'archive ouverte pluridisciplinaire $\mathbf{H A L}$, est destinée au dépôt et à la diffusion de documents scientifiques de niveau recherche, publiés ou non, émanant des établissements d'enseignement et de recherche français ou étrangers, des laboratoires publics ou privés. 


\title{
Tracing Biogenic Links of Natural Organic Substances at the Molecular Level with Stable Carbon Isotopes : $n$-Alkanes and $n$-Alkanoic Acids from Sediments
}

\author{
Eric A. LICHTFOUSE* and James W. COLLISTER ${ }^{\#}$ \\ Université Pierre et Marie Curie, INRA, CNRS URA 196, 75252 Paris Cedex 05, France. \\ \#University of Bristol, School of Chemistry, Cantock's Close, Bristol, England.
}

Abstract: the ${ }^{13} \mathrm{C} /{ }^{12} \mathrm{C}$ compositions of $n$-alkanes and $n$-alkanoic acids from Eocene sediments are correlated in the 2029 carbon number range.

$n$-Alkanes are an important class of natural compounds occurring almost ubiquitously in organic-rich sediments such as soils, petroleums and coals ${ }^{1}$. Although extensively studied, the origin of sedimentary $n$ alkanes is still unclear, mainly because of the lack of structural information of these substances. They might derive from biological aliphatic precursors such as $n$-alkanes, $n$-alkohols, $n$-alkanoic acids or biopolymers ${ }^{1-3}$. Recent studies suggest that ${ }^{13} \mathrm{C} /{ }^{12} \mathrm{C}$ compositions of molecular fossils could provide more information about their possible precursors in living organisms ${ }^{4}$. We would like now to report the correlation of $n$-alkanes and $n$-alkanoic acids from Eocene sediments by isotopic means.

The geological samples studied belong to the lacustrine Eocene formation ( $60 \mathrm{x} 10^{6}$ years) of Green River (Colorado, USA) and are located at depths varying between $300 \mathrm{~m}$ and $800 \mathrm{~m}$. Separation procedures and isotopic analysis have been previously described ${ }^{4,5}$. The following isotopic compositions were obtained (carbon number, $\delta \%$ ):

At 312 m depth: $n$-alkanes: (17, -36.8); (18, -31.7); (20, -31.9); (21, -30.2); (22, -32.0); (23, -30.0); (24, $31.0)$; (25, -30.5); (26, -29.9); (27, -29.8); (28, -29.6). n-Alkanoic acids: (18, -30.0); (19, -31.6); (20, $31.4)$; (21, -31.9); (22, -31.3); (23, -33.6); (24, -31.5); (25, -31.8); (26, -30.2); (27, -30.3); (28, -29.2); (29, 28.6).

At 778 m depth: $n$-alkanes: (17, -32.4); (18, -32.2); (20, -32.2); (21, -31.9); (22, -31.9); (23, -31.6); (24, $31.1)$; (25, -31.1); (26, -31.2); (27, -31.2); (28, -30.4). n-Alkanoic acids: (18, -29.2); (19, -32.6); (20, $33.2)$; (21, -32.6); (22, -32.5); (23, -32.6); (24, -32.3); (25, -32.1); (26, -32.2); (27, -32.1); (28, -32.3); (29, $32.1)$. 

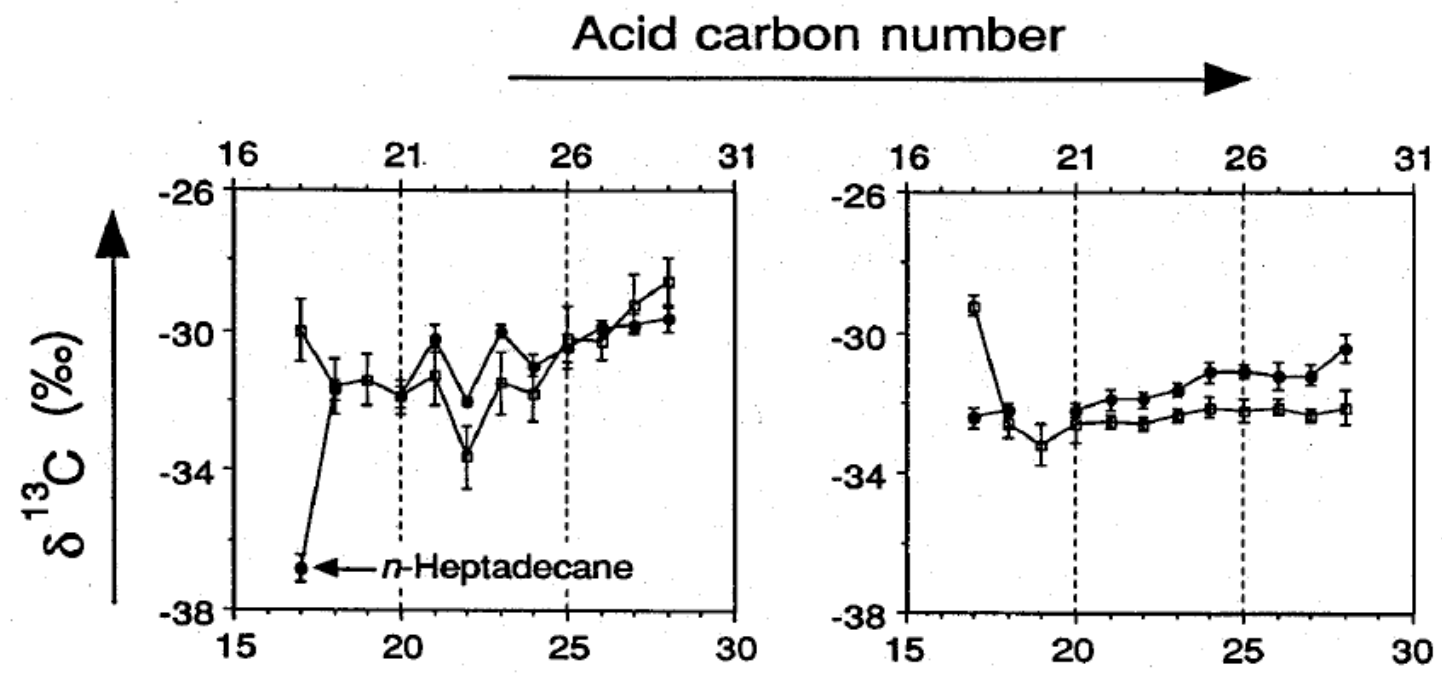

\section{Alkane carbon number}

\section{$\longrightarrow$ - - Alkanes \\ - $n$-Alkanoic acids}

Fig. 1. Isotopic compositions of $n$-alkanes and $n$-alkanoic acids at $312 \mathrm{~m}$ (left) and $718 \mathrm{~m}$ depth (right).

In the 20-29 carbon number range, the isotopic compositions of $\mathrm{x}$ carbon-numbered $n$-alkanes and $\mathrm{x}+1$ carbon-numbered $n$-alkanoic acids are close and display similar variations with increasing carbon number (Figure 1). Since various carbon sources with various isotopic compositions are available along the food chain, this correlation between two classes of organic substances suggests their biogenic link. Moreover, $n$-alkanes, which are seldom in living organisms, could derive from $n$-alkanoic acids occurring ubiquitously in eukaryots and eubacteria as triglyceride esters. This correlation also suggests the formation of alkane via decarboxylation ${ }^{2}$, accounting probably for the large amounts of carbon dioxide produced in sediments $^{1}$. Alternatively, the high isotopic composition difference observed between $n$-heptadecane and $n$-octadecanoic acid could arise from a different pathway of formation.

\section{REFERENCES}

1. Tissot, B. P., Welte, D. H. Petroleum Formation and Occurrence; Springer: Berlin. 1984.

2. Cooper, J. E., Bray, E. E. Geochim. Cosmochim. Acta 1963, 27, 1113-1127. Behar, F. H., Albrecht, P. Org. Geochem. 1984, 6, 597-604.

3. Tegelaar, E. W., Matthezing, R. M., Jansen, J. B. H., Horsfield, B., de Leeuw, J. W. Nature 1989, 342, 529-531.

4. Hayes, J. M., Takigiku, R., Ocampo, R., Callot, H. J., Albrecht, P. Nature 1987, 329, 48-51. Freeman, K. H., Hayes, J. M., Trendel, J. M., Albrecht P. Nature 1990, 343, 254-256.

5. Lichtfouse, E., Freeman, K. H., Collister, J. W., Merritt, D. A., J. Chromatogr. 1991, 585, 177-180 and refs. therein. 